\title{
Performance of Different Parts of Planting Materials and Plant Geometry on Oil yield and Suckers Production of Menthol- mint (Mentha arvensis L.) during Winter Season
}

\author{
Rakesh Kumar*, R.K. Upadhyay, Venkatesha K.T., R.C. Padalia, \\ A.K. Tiwari and Sonveer Singh
}

CSIR-CIMAP Research Centre Pantnagar PO-Dairy Farm Nagla-263149, US Nagar (UK), India

A B S T R A C T

\section{Ke ywords \\ Planting materials, Plant geometry, Oil yield, Suckers yield, Menthol-mint \\ Article Info \\ Accepted: \\ 10 December 2018 \\ Available Online: \\ 10 January 2019}

Field experiment was conducted during 2017-18 at the research farm of CSIR-CIMAP Research Centre Pantnagar to evaluate the performance of different sources of planting materials and plant geometry on oil yield and suckers production of Menthol-mint (Mentha arvensis L.) under tarai region of Uttarakhand. The studies involved three source of planting materials $\left(\mathrm{P}_{1}\right.$-Whole shoot; $\mathrm{P}_{2}$-Upper portion of shoot and $\mathrm{P}_{3}$-Lower portion of shoot) and three plant geometry $\left(S_{1}-50 \times 15 \mathrm{~cm} ; S_{1}-50 \times 30 \mathrm{~cm}\right.$ and $S_{1}-50 \times$ Running) were applied. The study revealed that, planted as whole shoots resulted in higher suckers yields $(89.78 \mathrm{q} / \mathrm{ha})$ as evident from higher oil yield $(102.76 \mathrm{~kg} / \mathrm{ha})$. Among the planting distance, broader spacing showed higher yield of oil $(95.31 \mathrm{~kg} / \mathrm{ha})$ and suckers $(83.52 \mathrm{q} / \mathrm{ha})$ in menthol-mint during experimentation.

\section{Introduction}

Menthol mint (Mentha arvensis L.) is herbaceous perennial medicinal and aromatic crop growing to height of $20-90 \mathrm{~cm}$ and belongs to the family lamiaceae. Mint is a potential source of natural menthol and dementholized oil and is cultivated in the tropics and subtropical countries worldwide. Essential oils of mint especially containing varieties of aroma chemicals and major one is menthol used in medicines for cold remedies, cosmetics, mouth washes and also used as flavouring agent in various types of confectionaries and dental cream 1 . The area under menthol mint cultivation in India is estimated to be 0.15 million hectares with annual production of 20,000 metric tonnes of essential oil. The crop is commercially cultivated in tarai and central part of Uttar Pradesh (Barabanki, Raebareli, Rampur, Bareli, Badaun, Moradabad, Amroha, Rudrapur Bilaspur), Punjab, Bihar and Haryana2. The plant on hydro distillation yields essential oil containing about 70-80\% menthol, which is used in various pharmaceutical, food and cosmetic preparations. Besides China and USA, India is a major producer of mint oil mostly exported to USA and European countries. Since during 
the last a few decades, many types of research and development viz. nutrient management, weed management, organic input, integrated nutrient management etc. have been done for increasing the yield and yield contributing characters of mint. Due to conventional breeding research and developmental techniques, it is not helpful increasing the yield of mint oil. It is thought to increase the yield and yield contributing characters of mint (Mentha arvensis L.) by changing or alter the phenotype the plant.

The phenotype of the plant can be changed by nipping at specific time (cutting of apical portion in each branch of mint), by this activity the mint plant may provide higher herb and oil yield. The present investigation was undertaken to develop appro-priate a new agrotechnology for mint crop which can increase the yield and yield contributing characters. This study aimed to determine the optimum sowing date and plant density of Basil for achievement of maximum oil and seed yields under Tarai region of Uttarakhand, India.

\section{Materials and Methods}

A field experiment was conducted at the research farm of CSIR-Central Institute of Medicinal and Aromatic Plant, Research Centre, Pantnagar (Udham Singh Nagar) Uttarakhand, India during 2017-18. The experimental site is located between $29^{\circ} \mathrm{N}$ latitude and $79.38^{\circ} \mathrm{E}$ longitude and at an altitude of $243 \mathrm{~m}$ above mean sea level. The maximum temperature ranges between 35 to $45^{\circ} \mathrm{C}$, and minimum between 2 to $5^{\circ} \mathrm{C}$. The experimental soil was sandy-loam in texture, neutral in reaction $(7.2 \mathrm{pH})$, medium in organic carbon $(0.52 \%)$, low in available nitrogen (135 kg ha-1), and medium in available phosphorus ( $\left.13 \mathrm{~kg} \mathrm{ha}^{-1}\right)$ as well as in potassium $\left(140 \mathrm{~kg} \mathrm{ha}^{-1}\right)$. The Mentha arvensis cv. CIM-Kranti was taken as experimental crop. The experimental design was split plot design with thrice replications. The main plot treatments were three source of planting materials $\left(\mathrm{P}_{1}\right.$-Whole shoot; $\mathrm{P}_{2}$-Upper portion of shoot and $\mathrm{P}_{3}$-Lower portion of shoot) and sub-plot three planting distance $\left(\mathrm{S}_{1}-50 \times 15, \mathrm{~S}_{2}\right.$ $50 \times 30$ and $\mathrm{S}_{3}-50 \times$ running $\mathrm{cm}$ ) were applied and each experimental plot was kept with $5 \times 5$ $\mathrm{m}^{2}$. The recommended dose of fertilizer was applied in the form of N: P: K @ 120:60:40 $\mathrm{kg} /$ ha through DAP, Urea and MOP. The crop was kept free from weeds by hand weeding. Sampling was performed from 4 middle rows in appropriate times. Plants were harvested at physiological maturity stage when plants lower leaves turn into yellowed. Five plants randomly were selected in each plot to measure the plant height, crop spread, herbage yield, oil and suckers yield. The data relating to each character were analyzed statistically by applying the technique of analysis of variance and the significance was tested by "F" test (Gomez and Gomez, 1984).

\section{Results and Discussion}

\section{Growth attributes}

Crop growth attributes data (Table 1) revealed that taller plants $(51.89 \mathrm{~cm})$ with maximum crop spread $(72.67 \mathrm{~cm})$ was recorded in $\mathrm{P}_{1^{-}}$ Whole shoot treatment which was significantly higher to $\mathrm{P}_{2}$-Upper portion of shoot (top plant part) and $\mathrm{P}_{3}$-Lower portion of shoot (lower plant part) except $\mathrm{P}_{2}$-Upper portion of shoot in crop spread $(68.33 \mathrm{~cm})$ which is at par with $\mathrm{P}_{1}$-Whole shoot treatment, however, $\mathrm{P}_{2}$-Upper portion of shoot was also received maximum crop height $(48.11 \mathrm{~cm})$ and crop spread $(68.33 \mathrm{~cm})$ as compared to $\mathrm{P}_{3^{-}}$ Lower portion of shoot treatment during experimentation (Table 1). It was might be due to better growth and performance of plant part which supported growth parameters in planting treatment. Among the spacing treatments, wider space $\left(S_{2}-50 \times 30 \mathrm{~cm}\right)$ 
recorded the highest plant height $(53.33 \mathrm{~cm})$ and crop spread $(72.11 \mathrm{~cm})$, respectively, which was at par with closer spacing $\left(\mathrm{S}_{1^{-}}\right.$ $50 \times 15 \mathrm{~cm})$ in crop spread only and significantly superior to $\left(\mathrm{S}_{3}-50 \times\right.$ running $)$ treatment. However, plant spacing $\left(S_{1}-50 \times 15\right.$ $\mathrm{cm})$ also showed that significantly higher plant height (49.00) and crop spread (64.89 cm) as compared to spacing $\left(\mathrm{S}_{3}-50 \times\right.$ running) during experimentation. Similar findings were also reported by Anwar et al., 2010; Chand et al., 2006 \& 12; Kothari et al., 1987 and Kumar et al., 2002.

\section{Herbage and suckers yield}

Herbage and suckers yield is considered to be a function of various source of planting materials were planted (Table 1). The highest herbage (172.74 q/ha) and suckers yield (89.18 q/ha) were recorded by $\mathrm{P}_{1}$-Whole shoot treatment which was significantly higher to $\mathrm{P}_{2}$-Upper portion of shoot (top plant part) and $\mathrm{P}_{3}$-Lower portion of shoot (lower plant part), however, $\mathrm{P}_{2}$-Upper portion of shoot (top plant part) was also received higher herbage (158.88 $\mathrm{q} / \mathrm{ha})$ and suckers yield (73.54 q/ha) as compared to $\mathrm{P}_{3}$-Lower portion of shoot (lower plant part) treatment during experimentation (Table 1).

Among the plant spacing treatments, wider space $\left(S_{2}-50 \times 30 \mathrm{~cm}\right)$ was recorded the highest herbage yield (167.07 q/ha) and suckers yield (83.52 q/ha), respectively, in comparison to closer spacing $\left(\mathrm{S}_{1}-50 \times 15 \mathrm{~cm}\right)$ and $\left(\mathrm{S}_{3^{-}}\right.$ $50 \times$ running $)$ treatment. Plant spacing $\left(\mathrm{S}_{1^{-}}\right.$ $50 \times 15 \mathrm{~cm}$ ) also showed that significantly higher herbage yield (167.07 q/ha) and suckers yield (83.52 q/ha) as compared to $\mathrm{S}_{3^{-}}$ $50 \times$ running spacing. However, spacing $\left(\mathrm{S}_{3^{-}}\right.$ $50 \times$ running) treatment was received least herbage yield (137.67 q/ha) and suckers yield $(51.18 \mathrm{q} / \mathrm{ha})$ as compared to both wider spacing $\left(\mathrm{S}_{2}-50 \times 30 \mathrm{~cm}\right.$ and $\left.\mathrm{S}_{1}-50 \times 15 \mathrm{~cm}\right)$ treatment during experimentation (Table 1).
Its might be due to influenced by closer and wider spacing on herbage and suckers yield $\mathrm{m}^{-}$ 2 contributed maximum yield which ultimately increased the yield. Similar results were supported by Nakawuka et al., 2014, Patra et al., 2000, Ram et al., 1998, 2006 \& 10, Ram and Kumar, 1998 and Rathi et al., 2014, Saxena and Singh, 1996 \& 1998 and Shormin, 2005.

\section{Oil content and oil yield}

Oil yield is considered to be a function of various yield attributing characters viz., oil content $/ \mathrm{kg}$ biomass and biomass yield. Oil content and oil yield was significantly influenced by source of planting materials (Table 1). The highest Oil content $(0.60 \%)$ and oil yield $(102.76 \mathrm{~kg} / \mathrm{ha})$ recorded by $\mathrm{P}_{1^{-}}$ Whole shoot treatment which was significantly higher to $\mathrm{P}_{2}$-Upper portion of shoot (top plant part) and $\mathrm{P}_{3}$-Lower portion of shoot (lower plant part), however, $\mathrm{P}_{2}$-Upper portion of shoot (top plant part) was also received higher oil yield $(92.72 \mathrm{~kg} / \mathrm{ha})$ as compared to $\mathrm{P}_{3}$-Lower portion of shoot (lower plant part) treatment during experimentation (Table 1).

Among the plant spacing treatments, wider space $\left(\mathrm{S}_{2}-50 \times 30 \mathrm{~cm}\right)$ was recorded the highest oil content $(0.58 \%)$ and oil yield (95.31 $\mathrm{kg} / \mathrm{ha})$ in comparison to closer spacing $\left(\mathrm{S}_{1^{-}}\right.$ $50 \times 15 \mathrm{~cm})$ and $\left(\mathrm{S}_{3}-50 \times\right.$ running $)$ treatment. However, spacing $\left(\mathrm{S}_{3}-50 \times\right.$ running $)$ treatment was received least oil content $(0.56 \%)$ and essential oil yield $(77.82 \mathrm{~kg} / \mathrm{ha})$ as compared to both wider spacing $\left(\mathrm{S}_{2}-50 \times 30 \mathrm{~cm}\right.$ and $\mathrm{S}_{1^{-}}$ $50 \times 15 \mathrm{~cm})$ treatment during experimentation (Table 1). Its might be due to influenced by planting part and closer and wider spacing on oil content and oil yield either decreased or increased. Similar results were supported by Singh et al., 1989, 1998, 1999 \& 2000 and Upadhyay et al., 2014. 
Table.1 Performance of different source of planting materials and spacing on oil and suckers production of Mentha arvensis

\begin{tabular}{|c|c|c|c|c|c|c|c|c|}
\hline Treatments & $\begin{array}{c}\text { Plant } \\
\text { Height } \\
\text { (cm) }\end{array}$ & $\begin{array}{c}\text { Crop } \\
\text { Spread } \\
(\mathrm{cm})\end{array}$ & $\begin{array}{c}\text { Herbage } \\
\text { yield } \\
\left(\mathrm{kg} / \mathrm{m}^{2}\right)\end{array}$ & $\begin{array}{c}\text { Herbage yield } \\
\text { (q/ha) }\end{array}$ & $\begin{array}{c}\text { Suckers } \\
\text { yield } \\
\left(\mathrm{kg} / \mathrm{m}^{2}\right)\end{array}$ & $\begin{array}{c}\text { Suckers yield } \\
\text { (q/ha) }\end{array}$ & Oil (\%) & $\begin{array}{c}\text { Oil yield } \\
\text { (kg/ha) }\end{array}$ \\
\hline \multicolumn{9}{|l|}{ Planting Materials } \\
\hline$P_{1}$-Whole shoot & 51.89 & 72.67 & 1.73 & 172.74 & 0.89 & 89.18 & 0.60 & 102.76 \\
\hline $\mathbf{P}_{2}$-Upper portion of shoot & 48.11 & 68.33 & 1.59 & 158.88 & 0.74 & 73.54 & 0.58 & 92.72 \\
\hline$P_{3}$-Lower portion of shoot & 42.78 & 55.11 & 1.31 & 131.12 & 0.42 & 41.68 & 0.53 & 69.36 \\
\hline SEm \pm & 1.13 & 3.62 & 0.03 & 3.46 & 0.04 & 4.25 & 0.02 & 3.38 \\
\hline $\operatorname{LSD}(p=0.05)$ & 3.13 & 10.05 & 0.10 & 9.61 & 0.12 & 11.80 & 0.06 & 9.38 \\
\hline \multicolumn{9}{|l|}{ Planting Distance } \\
\hline$S_{1}-(50 \times 15 \mathrm{~cm})$ & 53.33 & 72.11 & 1.58 & 158.01 & 0.70 & 69.70 & 0.58 & 91.70 \\
\hline $\mathrm{S}_{2}-(50 \times 30 \mathrm{~cm})$ & 49.00 & 64.89 & 1.67 & 167.07 & 0.84 & 83.52 & 0.57 & 95.31 \\
\hline $\mathrm{S}_{3}-(50 \times$ Running $)$ & 40.44 & 59.11 & 1.38 & 137.67 & 0.51 & 51.18 & 0.56 & 77.82 \\
\hline SEm \pm & 2.52 & 2.56 & 0.03 & 2.75 & 0.04 & 3.65 & 0.04 & 6.53 \\
\hline $\operatorname{LSD}(p=0.05)$ & 5.50 & 5.58 & 0.06 & 5.99 & 0.08 & 7.96 & NS & 14.24 \\
\hline Interaction & NS & NS & NS & NS & $*$ & $*$ & NS & NS \\
\hline
\end{tabular}

Table.1a Interaction effect of planting materials and spacing on suckers yield $\left(\mathrm{kg} / \mathrm{m}^{2}\right)$ of Mentha arvensis

\begin{tabular}{|c|c|c|c|c|}
\hline Interaction & $\begin{array}{l}\mathrm{S}_{1}-(\mathbf{5 0} \times 15 \\
\mathrm{cm})\end{array}$ & $\begin{array}{l}S_{2}-(50 \times 30 \\
\text { cm) }\end{array}$ & $\begin{array}{c}\mathbf{S}_{3^{-}} \\
(50 \times \text { Running })\end{array}$ & $\begin{array}{c}\text { Averag } \\
\text { e }\end{array}$ \\
\hline$P_{1}$-Whole shoot & 0.94 & 1.15 & 0.59 & 0.89 \\
\hline $\mathbf{P}_{2}$-Upper portion of shoot & 0.74 & 0.92 & 0.54 & 0.74 \\
\hline$P_{3}$-Lower portion of shoot & 0.41 & 0.44 & 0.40 & 0.42 \\
\hline Average & 0.70 & 0.84 & 0.51 & 0.68 \\
\hline SEm \pm for spacing at the same level of planting parts. & 0.06 & & & \\
\hline $\mathrm{CD}(P=0.05)$ & 0.14 & & & \\
\hline $\begin{array}{l}\text { SEm } \pm \text { for planting parts at the same or different levels of } \\
\text { spacing. }\end{array}$ & 0.07 & & & \\
\hline $\mathrm{CD}(P=0.05)$ & 2.42 & & & \\
\hline
\end{tabular}


Table.1b Interaction effect of planting materials and spacing on suckers yield (q/ha) of Mentha arvensis

\begin{tabular}{|c|c|c|c|c|}
\hline Interaction & $\begin{array}{l}\mathrm{S}_{1}-(50 \times 15 \\
\mathrm{cm})\end{array}$ & $\begin{array}{c}\mathbf{S}_{2^{-}} \\
(\mathbf{5 0 \times 3 0} \\
\mathrm{cm})\end{array}$ & $\begin{array}{c}\mathrm{S}_{3^{-}} \\
(50 \times \text { Running })\end{array}$ & Average \\
\hline$P_{1}$-Whole shoot & 94.00 & 114.60 & 58.93 & 89.18 \\
\hline $\mathbf{P}_{2}$-Upper portion of shoot & 74.37 & 91.97 & 54.30 & 73.54 \\
\hline $\mathbf{P}_{3}$-Lower portion of shoot & 40.73 & 44.00 & 40.30 & 41.68 \\
\hline Average & 69.70 & 83.52 & 51.18 & 68.13 \\
\hline $\begin{array}{l}\text { SEm } \pm \text { for spacing at the same level } \\
\text { of planting parts. }\end{array}$ & 6.33 & & & \\
\hline $\mathrm{CD}(P=0.05)$ & 13.79 & & & \\
\hline $\begin{array}{l}\text { SEm } \pm \text { for planting parts at the same } \\
\text { or different levels of spacing. }\end{array}$ & 6.69 & & & \\
\hline $\mathrm{CD}(P=0.05)$ & 2.42 & & & \\
\hline
\end{tabular}

From the above discussion, consequently, it may be concluded that menthol-mint was most responsive to whole shoot treatment and wider space $\left(\mathrm{S}_{2}-50 \times 30 \mathrm{~cm}\right)$ for growth, essential oil and suckers yield in comparison with upper portion of shoot (top plant part) and lower portion of shoot (lower plant part) treatments along with closer $\left(\mathrm{S}_{1}-50 \times 15 \mathrm{~cm}\right)$ and $\left(\mathrm{S}_{3}-50 \times\right.$ running) spacing treatment under irrigated conditions of Pantnagar. Thus, it is concluded that combined application of whole shoot treatment and wider spacing $\left(\mathrm{S}_{2}-50 \times 30\right.$ $\mathrm{cm})$ may serve as a potent source for the ecofriendly, economically, and quality cultivation of menthol-mint in northern Indian plain zones.

\section{Acknowledgment}

Authors are thankful to the Director, CSIRCentral Institute of Medicinal and Aromatic Plants (CIMAP) Lucknow, U.P. (India) for providing necessary facilities and encouragement.

\section{References}

Anwar, M., Chand, S., Patra, D.D., 2010. Effect of graded level of NPK on fresh herb yield, oil yield and oil composition of six cultivars of menthol mint. Indian J. Nat. Prod. Resour. 1(1), 74-79.

Chand, S., Anwar, M., Patra, D.D., 2006. Influence of long-term application of organic and inorganic fertilizer to build up soil fertility and nutrient uptake in mintmustard cropping sequence. Соттип. Soil Sci. Plant Anal. 37, 63-76.

Chand. S., Pandey, A., Patra, D.D., 2012. Influence of nickel and lead applied in combination with vermicompost on growth and yield of heavy metals by Mentha arvensis cv. 'Koshi'. Indian J. Nat. Prod. Resour. 3(2), 256-261.

Gomez, K.A., and Gomez, A.A., (1984), Statistical procedures for agricultural research (Second Eds.). An International Rice Research Institute Book. John Wiley and Sons.

Kothari, S.K., Singh, V., Singh, K., 1987. Response of Japanese mint (Mentha arvensis L. ) to varying levels of nitrogen application in Uttar Pradesh foot hills. Indian J. Agr. Sci. 57 (11), 795-800.

Kumar, S., Bahl, J.R., Bansal, R.P., Gupta, A.K., Singh. V., Sharma, S., 2002. High economic returns from companion and relay cropping of bread wheat and menthol mint in the winter-summer season in north Indian plains. Ind. Crop 
Prod. 15, 103-114.

Nakawuka, P., Peters, T.R., Gallardo, K.R., Gonzalez, D.T., Okwany, R.O., Walsh, D.B., 2014. Effect of deficit irrigation on yield, quality and costs of the production of native spearmint. J. Irrig. Drain. Eng. 20, 140- 149.

Patra, D.D., Anwar, M. and Chand, S. (2000). Integrated nutrient management and waste recycling for restoring soil fertility and productivity in Japanese mint (Mentha arvensis) and mustard (Brassica juncea) sequence in Uttar Pradesh, India. Agric. Ecosyst. Environ, 80: 260-75.

Ram, D., Ram, M. and Singh, R. (2006). Optimization of water and nitrogen application to menthol mint (Mentha arvensis L.) through sugarcane trash mulch in a sandy loam soil of semiarid subtropical climate. Bioresour. Technol. 97: 886-893.

Ram, D., Ram, M., Rawat, G., 2010. Effect of moisture regimes, nitrogen rates and organic mulch on growth, accumulation pattern and yield of essential oil in menthol mint. Indian Perf. 54, 39-43.

Ram, M., Kumar, S., 1998. Yield and resource use optimization in late transplanted mint (Mentha arvensis) under sub-tropical conditions. J. Agron. Crop Sci. 180, 109112.

Ram, P., Patra, N.K., Kumar, B., Singh, H.B., Kumar, S., 1998. Productivity and economic viability in early and late planted Japanese mint (Mentha arvensis L.) Indian Perf. 42(4), 211-215.

Rathi, A.S., Kumar, A., Mishra, M.K., Kumar, R. Kant, L., 2014. Intercropping of menthol mint (Mentha arvensis L.) in bed planted wheat (Triticum aestivum L.) in Rampur district of Uttar Pradesh. J. Krishi Vigyan. 2( 2), 53-55.

Saxena, A. and Singh, J.N., 1998. Effect of irrigation, mulch and nitrogen on yield and composition of Japanese mint (Mentha arvensis L.) oil. Indian J. Agron. 43: 179-182.

Shormin, T., Khan, M.A.H., Alaungir, M. 2009. Response of different levels of nitrogen fertilizers and water stress on the growth and yield of Japanese mint. Bangladesh J. Sci. Ind. Res. 44(1), 137-145.

Singh, A., Singh, M., Singh, K., 1998. Use of nursery raised plantlets for delayed planting of Japanese mint (Mentha arvensis L.): an appropriate technology for small holders in India. Indian Perf. 42(2), 92-103.

Singh, M., Kothari, S.K. and Singh, D.V. (1989). Effect of irrigation and nitrogen on herbage and essential oil yields of Japanese mint (Mentha arvensis). J. Agric. Sci. 113: 277-279.

Singh, S., Singh, A., Singh V.P., 1999. Use of dust mulch and anti-transpirants for improving water use efficiency of menthol mint (Mentha arvensis L.). J. Med. Aromat. Plant Sci. 21, 29-33.

Singh, S.P., Tiwari, R.K. and Dubey, T. (2000). Studies on selection parameters in Mentha arvensis. Journal of Medicinal \& Aromatic Plant Sciences, 22: 443-446.

Upadhyay, R.K., Bahl, J.R., Verma, R.S., Padalia, R.S., Chauhan, A., Patra, D.D., 2014. New source of planting material for quality cultivation of menthol-mint (Mentha arvensis L.). Ind. Crop. Prod. 59, 184-188.

\section{How to cite this article:}

Rakesh Kumar, R.K. Upadhyay, K.T. Venkatesha, R.C. Padalia, A.K. Tiwari and Sonveer Singh. 2019. Performance of Different Parts of Planting Materials and Plant Geometry on Oil yield and Suckers Production of Menthol-mint (Mentha arvensis L.) during Winter Season. Int.J.Curr.Microbiol.App.Sci. 8(01): 1261-1266. doi: https://doi.org/10.20546/ijcmas.2019.801.133 